\title{
Acidosis promotes invasiveness of breast cancer cells through ROS-AKT-NF-KB pathway
}

\author{
Subash C. Gupta ${ }^{1,2}$, Ramesh Singh ${ }^{1,2}$, Radhika Pochampally ${ }^{1,2}$, Kounosuke Watabe ${ }^{1,3}$ \\ and Yin-Yuan Mo ${ }^{1,4}$ \\ ${ }^{1}$ Cancer Institute, University of Mississippi Medical Center, Jackson, MS \\ 2 Department of Biochemistry, University of Mississippi Medical Center, Jackson, MS \\ ${ }^{3}$ Department of Microbiology, University of Mississippi Medical Center, Jackson, MS \\ ${ }^{4}$ Department of Pharmacology and Toxicology, University of Mississippi Medical Center, Jackson, MS \\ Correspondence to: Yin-Yuan Mo, email: ymo@umc.edu \\ Keywords: Acidosis, AKT, NF-KB, Invasion, breast cancer, inflammation, ROS, tumor microenvironment \\ Received: August 15, $2014 \quad$ Accepted: September 24, $2014 \quad$ Published: September 25, 2014
}

This is an open-access article distributed under the terms of the Creative Commons Attribution License, which permits unrestricted use, distribution, and reproduction in any medium, provided the original author and source are credited.

\section{ABSTRACT}

It is well known that acidic microenvironment promotes tumorigenesis, however, the underlying mechanism remains largely unknown. In the present study, we show that acidosis promotes invasiveness of breast cancer cells through a series of signaling events. First, our study indicates that NF-KB is a key factor for acidosis-induced cell invasion. Acidosis activates NF-KB without affecting STAT3 activity; knockdown of NF-KB p65 abrogates the acidosis-induced invasion activity. Next, we show that the activation of NF-KB is mediated through phosphorylation and degradation of $\mathbf{I K B a}$; and phosphorylation and nuclear translocation of p65. Upstream to NF-kB signaling, AKT is activated under acidic conditions. Moreover, acidosis induces generation of reactive oxygen species (ROS) which can be suppressed by ROS scavengers, reversing the acidosis-induced activation of AKT and NF-KB, and invasiveness. As a negative regulator of AKT, PTEN is oxidized and inactivated by the acidosis-induced ROS. Finally, inhibition of NADPH oxidase (NOX) suppresses acidosis-induced ROS production, suggesting involvement of NOX in acidosis-induced signaling cascade. Of considerable interest, acidosis-induced ROS production and activation of AKT and NF-KB can be only detected in cancer cells, but not in non-malignant cells. Together, these results demonstrate a cancer specific acidosis-induced signaling cascade in breast cancer cells, leading to cell invasion.

\section{INTRODUCTION}

Majority of cancer deaths are caused by metastatic spread of cells from the primary tumor to a distant site. In order to metastasize, tumor cells first locally invade through surrounding extracellular matrix and stromal cell layers [1]. Tumor invasion and metastasis involve multiple interactions and complex crosstalk between tumor cells and their microenvironment [2]. It has been shown that the extracellular $\mathrm{pH}(\mathrm{pHe})$ within the microenvironment of breast tumors is significantly low (acidic) compared with that of normal tissue [3]. The low $\mathrm{pHe}$ (acidosis) in tumor microenvironment is mainly caused by a combination of poor vascular perfusion, regional hypoxia, and increased aerobic glycolysis (Warburg effect) and lactic acid production $[4,5]$. A previous study has shown that an increase in glucose uptake is associated with the transition from carcinoma in situ to invasive breast cancer [6]. In particular, highest regions of tumor invasion correspond to areas with the lowest $\mathrm{pHe}$ and tumor invasion does not occur in regions with normal or near normal $\mathrm{pHe}$ levels in a nude mouse model [7]. Moreover, oral sodium bicarbonate has been shown to reduce the formation of spontaneous and experimental breast cancer metastases to the lung [8]. These reports suggest that acidosis promotes breast cancer invasion; however, the underlying mechanism still remains elusive.

A key factor responsible for cell invasion is the proinflammatory transcription factor, nuclear factor (NF)- 
$\kappa \mathrm{B}$ [9]. NF- $\kappa \mathrm{B}$ is a ubiquitously expressed pleiotropic transcription factor that can be activated in response to a number of stimuli including low pHe [10-12]. Under normal conditions, NF- $\mathrm{kB}$ stays in the cytoplasm as a heterotrimeric complex consisting of the subunits $\mathrm{p} 50$, p65, and the inhibitory subunit I $\mathrm{KB} \alpha$. In response to inducing stimuli, I $\mathrm{KB}$ undergoes phosphorylation, ubiquitination and proteolytic degradation and the p65-p50 dimeric complex is then released in the cytoplasm. Next, the p65 subunit undergoes phosphorylation and moves into the nucleus where it binds to specific DNA sequence and activates the transcription of hundreds of genes [13].

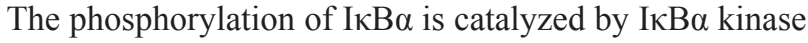
(IKK), which consists of three subunits, IKK- $\alpha$, IKK- $\beta$, and IKK- $\gamma$ (also called NEMO). Aberrant regulation of $\mathrm{NF}-\kappa \mathrm{B}$ and the signaling pathways that control its activity is linked with inflammation, drug/radiation resistance, and tumorigenic potential of cancer cells [14]. However, it is largely unclear how acidosis induces the NF- $\mathrm{kB}$ signaling, leading to cell invasion.

In the present work, we report that the activation of NF- $\mathrm{KB}$ is essential to acidosis-induced invasiveness of breast cancer cells. Moreover, acidosis induces production of reactive oxygen species (ROS), and activates PDK1 and AKT, leading to NF- $\mathrm{KB}$ activation. Finally, we show that this acidosis-mediated ROS-AKT-NF- $\mathrm{kB}$ signaling cascade is specific to cancer cells.

\section{RESULTS}

The purpose of this study was to dissect acidosismediated signaling pathways, leading to cell invasion in breast cancer. Although most experiments were performed in MDA-MB-231 and MCF-7, other cell lines were also used. Because the extracellular $\mathrm{pH}$ within the microenvironment of solid tumors including breast tumors is typically in the range of 6.5-6.9 [15, 16], we adjusted $\mathrm{pH}$ of the culture medium to 6.6 with $20 \mathrm{mM}$ 2-(N-morpholino)ethane-sulfonic acid and $20 \mathrm{mM}$ Tris (hydroxymethyl) aminomethane [11].

\section{Acidosis increases the invasion activity and induces $\mathrm{NF}-\mathrm{\kappa B}$ activation}

First, we investigated if acidosis can affect the invasion activity of breast cancer cells. MDA-MB-231 cells were cultured at $\mathrm{pH} 7.4$ or $\mathrm{pH} 6.6$ for 48 hours and then assessed in vitro in regular medium using Matrigel invasion chambers. The invasion activity under acidic conditions was a 3-fold higher than that cultured at $\mathrm{pH}$ 7.4 (Fig. 1A).

We then measured the activities of the proinflammatory transcription factor $\mathrm{NF}-\mathrm{\kappa B}$ under acidic conditions because NF- $\mathrm{\kappa B}$ is a key factor responsible for cell invasion. First, we found that low pHe was able to increase the nuclear NF- $\mathrm{BB}$ p65 in a time-dependent manner in both MCF-7 and MDA-MB-231 cells (Fig. $1 B)$. In contrast, acidosis had no effect on the activities of signal transducer and activator of transcription 3 (STAT3), another pro-inflammatory transcription factor (Fig. S1A). Second, luciferase reporter assays revealed a 2.6-fold induction of NF- $\mathrm{KB}$ activity under acidic conditions (Fig. 1C). Third, acidosis induced the redistribution of p65 from the cytoplasm to the nucleus, as determined by immunofluorescence staining (Fig. 1D). In addition, we found that acidosis induced the NF- $\mathrm{kB}$ downstream target CXCR4 which has been implicated in invasion and metastasis (Fig. S1B). Since regular culture medium often becomes acidic after cells are grown for a period of time, we replaced with fresh medium after every 10-12 hours. Cells cultured in $\mathrm{pH} 7.4$ medium for a period of 1 to 48 hours showed no change of the nuclear NF-kB-p65 (Fig. $\mathrm{S} 1 \mathrm{C}$ ). Collectively, these findings suggest that low $\mathrm{pHe}$ can induce NF- $\mathrm{kB}$ activation in breast cancer cells.

\section{Acidosis induces $I \kappa B \alpha$ phosphorylation and degradation}

Under normal conditions, I $\mathrm{B} B$, the inhibitory subunit of NF- $\kappa B$, holds NF- $\kappa B$ in an inactive state in the cytoplasm. The translocation of NF- $\mathrm{kB}$ to the nucleus is preceded by the phosphorylation, ubiquitination, and proteolytic degradation of IкB $\alpha$. We examined whether acidosis-induced NF- $\mathrm{KB}$ activation is mediated through I $\kappa \mathrm{B} \alpha$ phosphorylation and degradation. Cells were cultured in low $\mathrm{pH}$ medium for a period of 5 to 2880 minutes (48 hours) and cytoplasmic fraction was used to examine I $\kappa \mathrm{B} \alpha$ expression. We found that acidosis induced I $\mathrm{B} \alpha$ degradation in both MCF-7 and MDA-MB-231 cells (Fig. 2A), although the kinetics of degradation was different in two cell lines; IкB $\alpha$ was resynthesized after 16 hours (Fig. $2 A$ ). We then investigated whether acidosis induces $\mathrm{I} \kappa \mathrm{B} \alpha$ phosphorylation. Cells were exposed to normal or low $\mathrm{pH}$ medium in the presence of a proteasome inhibitor (MG-132) and Western blot was carried out using an antibody that recognizes the phosphorylated form of $\mathrm{I} \kappa \mathrm{B} \alpha\left(\mathrm{Ser}^{32}\right.$ and $\left.\mathrm{Ser}^{36}\right)$. Results revealed that acidosis did induce phosphorylation of I $\mathrm{KB} \alpha$ (Fig. $2 B$ ). The densitometric analyses using National Institutes of Health Image $\mathbf{J}$ software indicated that the acidosisinduced nuclear content of p 65 was reduced by $19 \%$ in the presence of proteasome inhibitor (Fig. 2C). Overall, these results suggest that acidosis-induced NF- $\mathrm{KB}$ activation is mediated through phosphorylation and degradation of $\mathrm{I} \kappa \mathrm{B} \alpha$. 
Knockdown of NF-KB p65 abrogates acidosisinduced invasion activity

To determine whether NF- $\mathrm{KB}$ activation plays a crucial role in acidosis-induced invasion activity, we silenced p65 by RNAi (Fig. 2D, left) before culturing MDA-MB-231 cells under acidic conditions followed by invasion assay. Acidosis-induced invasion activity of

A

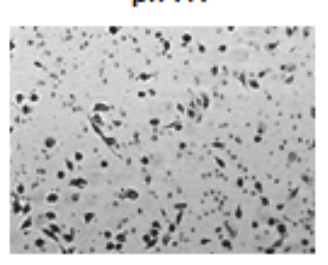

pH 6.6

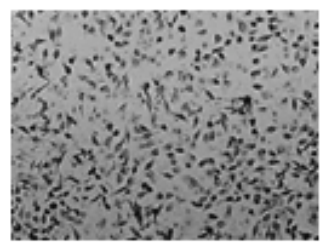

B

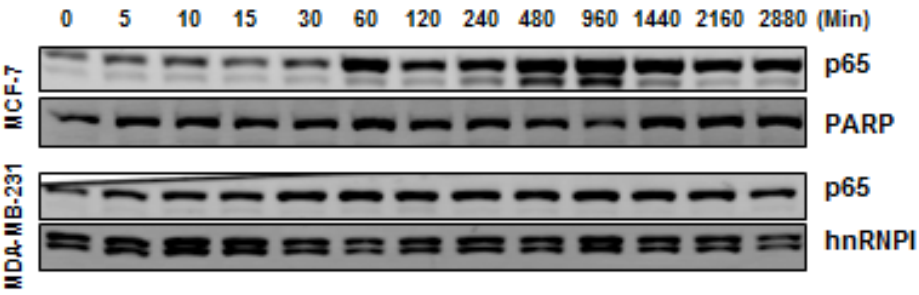

MDA-MB-231 cells was decreased from a 4.3-fold to a 1.7-fold when cells were transfected with p65 siRNA (Fig. 2D, right). These results suggest that an increase in invasion activity under acidic conditions is mediated through NF- $\mathrm{KB}$ activation.

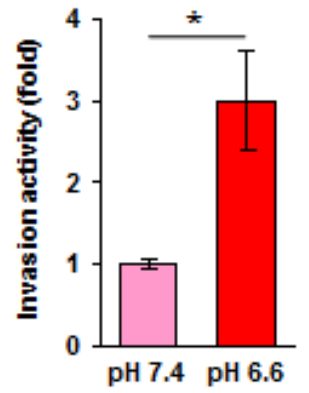

C
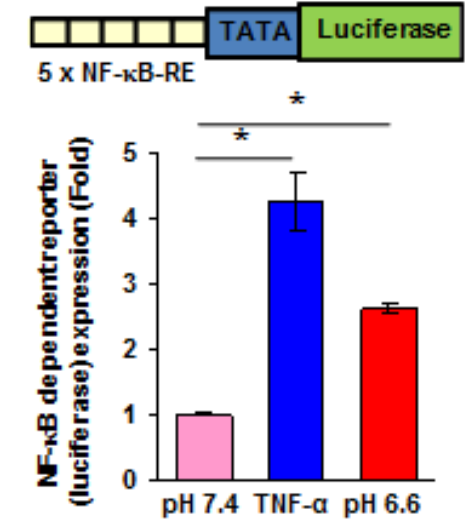

D

MCF-7

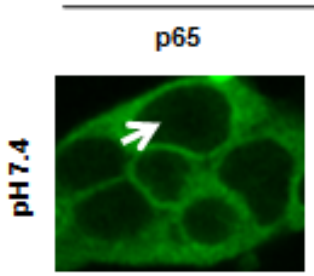

Nucleus
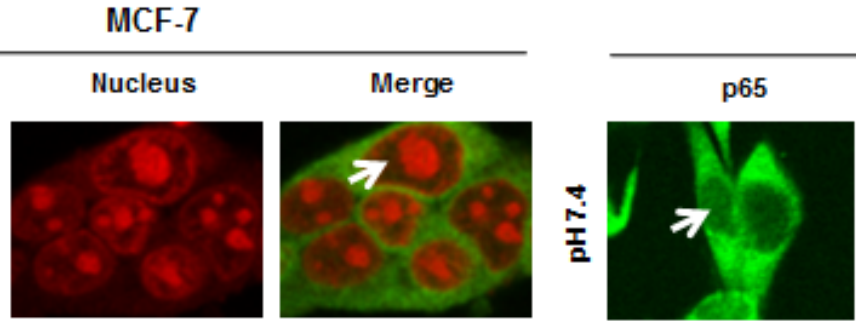

MDA-MB-231
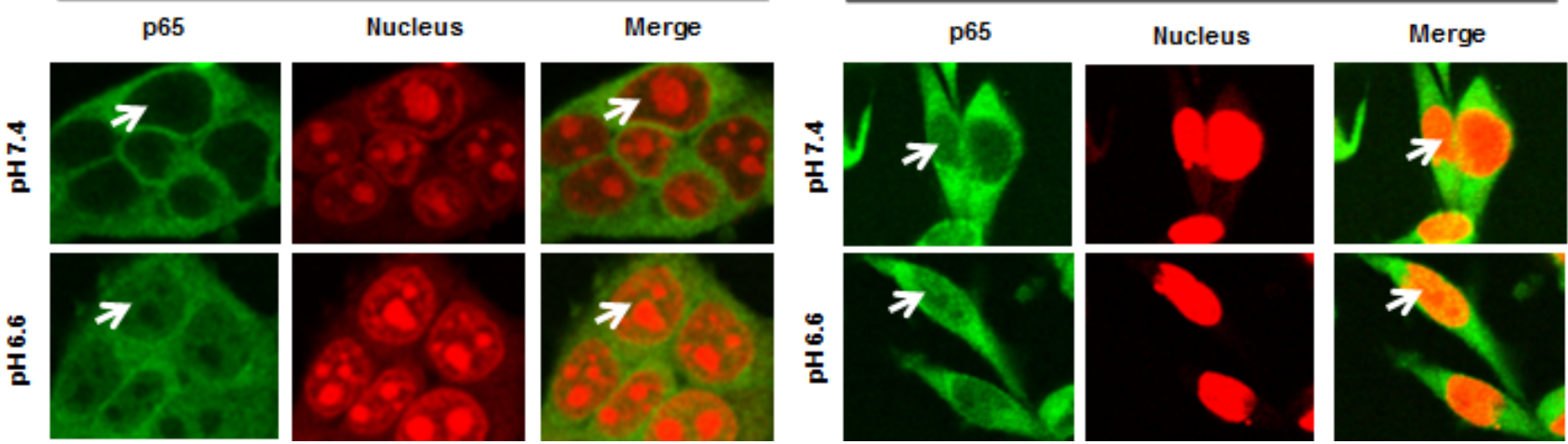

Figure 1: Acidosis increases invasive capacity and NF-KB activity. (A, left) MDA-MB-231 cells were cultured at $\mathrm{pH} 7.4$ or $\mathrm{pH}$ 6.6 for 48 hours and then assessed in vitro in regular medium using Matrigel invasion chambers. $(A$, right) Fold induction in the number of invaded cells at $\mathrm{pH} 6.6$ as compared to those cultured at $\mathrm{pH}$ 7.4. (B) Time-dependent effects of acidic environment on NF- $\mathrm{kB}$ p 65 nuclear translocation. Cells were cultured at $\mathrm{pH} 6.6$ for the indicated time, nuclear extracts were prepared and assayed for $\mathrm{p} 65$ content by Western blotting. (C) Acidic environment induces NF-kB-dependent reporter gene expression in MCF-7 cells. Cells were transiently transfected with a plasmid in which a luciferase reporter carries 5 copies of NF- $\mathrm{kB}$ response elements $(5 \mathrm{x}$ NF-kB-RE) in front of minimal promoter (TATA). Cells were then cultured at $\mathrm{pH} 7.4$ or $\mathrm{pH} 6.6$ for 12 hours and luciferase activity was measured using whole cell lysate. Where indicated, the cells cultured in normal medium were exposed to $0.5 \mathrm{nM} \mathrm{TNF}-\alpha$ for 12 hours. (D) Cellular localization of NF-kB p65 in breast cancer cells under acidic environment. Cells were cultured at $\mathrm{pH} 7.4$ or $\mathrm{pH} 6.6$ for 1 hour and analyzed for p65 localization by immunefluorescent staining. *, $p<0.05$. 


\section{Acidosis induces AKT activation}

Because NF- $\kappa B$ activation has been linked with activation of AKT, we investigated the effects of low pHe on the activity of AKT. First, exposure of cells to different $\mathrm{pH}$ conditions indicated that acidosis enhanced the phosphorylation of AKT at $\operatorname{Ser}^{473}$ (Fig. 3A). However, the total level of AKT was unaffected under the same conditions. Second, a time dependent increase in the phosphorylation of AKT at $\mathrm{Ser}^{473}$ (Fig. $3 B$ ) and $\mathrm{Thr}^{308}$ (Fig. $\mathrm{S} 2 A$ ) was observed at low $\mathrm{pH}$. Furthermore, normal $\mathrm{pHe}$ was unable to induce any change in the phosphorylation of AKT at Ser ${ }^{473}$ in MCF-7 cells (Fig. S2B). While the increase in AKT phosphorylation in MCF-7 cells was transient, MDA-MB-231 cells exhibited a persistent increase in AKT phosphorylation. We also investigated the phosphorylation of PDK1, a kinase upstream to AKT, and found that acidosis can activate PDK1 in a time-dependent manner in MCF-7 cells (Fig. 3C).

\section{Acidosis-induced activation of AKT and NF- $\kappa B$ is mediated through ROS generation}

Studies during the past decades have suggested that there are numerous cross-talks among ROS generation, and NF- $\mathrm{kB}$ and AKT activation [17]. We therefore investigated if ROS is required for acidosis-induced AKT and NF- $\mathrm{KB}$ activation. First, acidosis was found to induce ROS production in both MCF-7 and MDA-MB-231 cells as early as 5 minutes of exposure (Fig. 4A). Second, the ROS scavengers, GSH and NAC, abrogated the acidosisinduced ROS production (Fig. 4B). For example, the

A

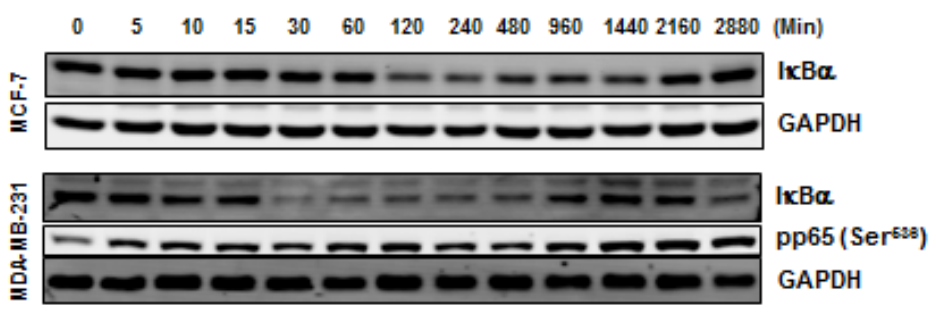

B

$+\quad+\quad-\quad \mathrm{pH} 7.4$ (45 Min)

- + + $\mathrm{pH} 6.6$ (45 Min)

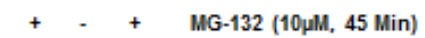

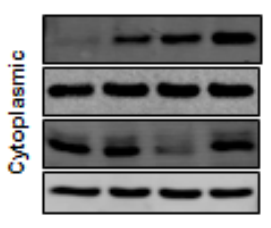

$\operatorname{plxB} \alpha\left(\right.$ Serev2ss$\left.^{02}\right)$

GAPDH

IxB $\alpha$

GAPDH

D

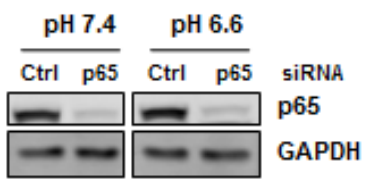

C
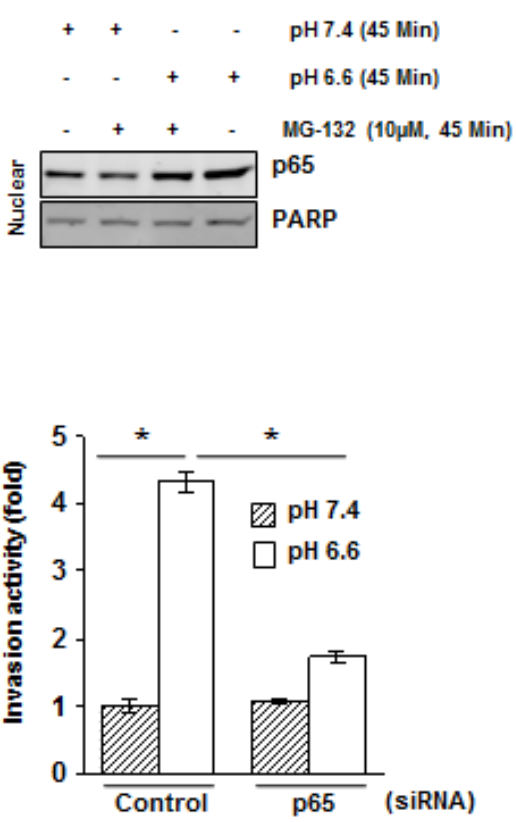

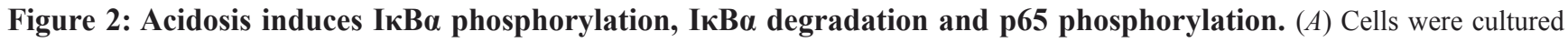
at $\mathrm{pH} 6.6$ for the indicated times, cytoplasmic extracts were prepared and analyzed for IкB $\alpha$ and pp65 by Western blotting. (B) Acidosis induces I $\mathrm{B} \alpha$ phosphorylation in MDA-MB-231 cells. Cells were cultured at $\mathrm{pH} 7.4$ or $\mathrm{pH} 6.6$ in absence or presence of MG-132 for 45

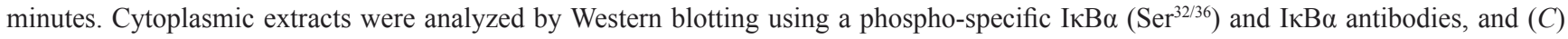
Nuclear extracts were analyzed for p65. (D) Gene silencing of NF-kB-p65 abolishes acidosis induced invasion activity of MDA-MB-231 cells. (Left), cells were transfected with p65 siRNA and control siRNA in normal medium. After $24 \mathrm{~h}$, cells were cultured under normal or acidic medium for 24 hours, and whole-cell extracts were analyzed by Western blotting using p65 antibody. (Right), the p65 silenced cells cultured under normal and acidic conditions were assessed in vitro for invasion activity using Matrigel chambers. ${ }^{*}, p<0.05$. 
generation of ROS was reduced from an 11.8-fold to a 1-fold in MDA-MB-231 cells (Fig. 4B).

To examine if acidosis-induced NF- $\kappa \mathrm{B}$ and AKT activation is mediated through ROS generation, we pretreated the cells with 1,5 and $10 \mathrm{mM}$ GSH or NAC before culturing them under acidic conditions. We found that both GSH and NAC suppressed acidosis-induced NF$\kappa \mathrm{B}$ and AKT activation in a dose-dependent manner (Fig. $4 C$ ). The total level of AKT was unaffected under the same conditions.

To examine the possibility of involvement of ROS in acidosis-induced invasion activity, MDA-MB-231 cells were pretreated with $10 \mathrm{mM}$ NAC, cultured under acidic conditions for 48 hours and then invasion assay was performed. The invasion activity was increased by a 2.8 fold under acidic conditions (Fig. 4D). However, when cells were pretreated with NAC, the activity was increased by only about a 1.4-fold. These results suggest that ROS plays a critical role in acidosis-induced invasion activity of breast cancer cells.

\section{Acidosis does not activate AKT and NF- $\mathrm{KB}$ in non-malignant breast cells}

Next, we examined the effects of acidosis on non-malignant breast cells. The non-malignant breast cells (MCF-10A) and breast cancer cells (MCF-7) were cultured under low $\mathrm{pH}$ conditions for 30 and 60 minutes and $\mathrm{NF}-\kappa \mathrm{B}$ activation was examined. While acidosis induced NF- $\mathrm{NB}$ activation in MCF-7 cells, no activation was observed in MCF-10A cells (Fig. 5A). Similarly, we detected acidosis-induced AKT and PDK1 activation in MCF-7 cells but not in MCF-10A cells (Fig. 5B and 5C). We then investigated whether this cancer cell specific acidosis-induced NF- $\kappa \mathrm{B}$ and AKT activation is due to a difference in ROS production. Both MCF-7 and MCF-10A cells were cultured under normal or low $\mathrm{pH}$ conditions for 60 minutes before measurement of ROS. While acidosis induced an 8.6-fold increase in ROS generation in MCF7 cells, only a 1.8-fold increase was observed in MCF10A cells (Fig. 5D). These results suggest that the effects of acidosis on NF- $\kappa \mathrm{B}$ signaling pathway is cancer cell specific and ROS may contribute to this specificity.

A

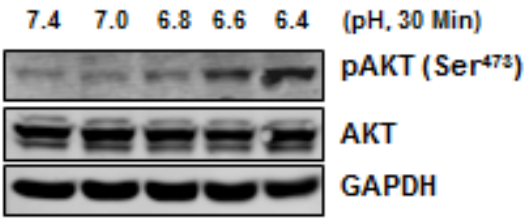

B

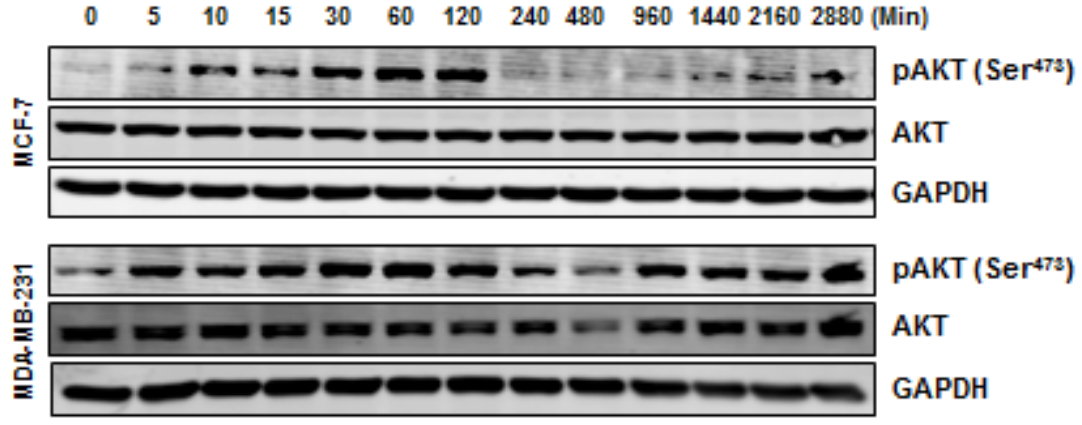

C

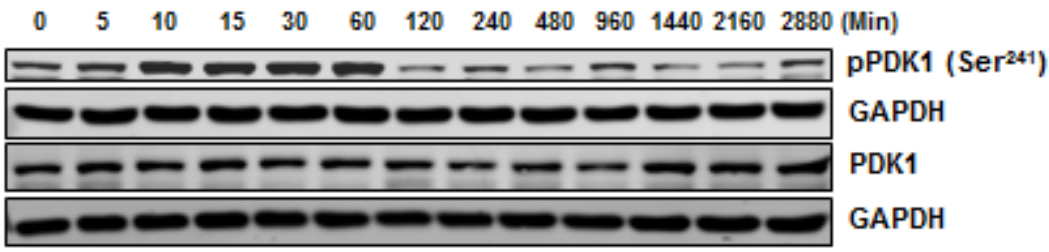

Figure 3: Acidosis induces phosphorylation of AKT and PDK1. $(A)$ MCF-7 cells were cultured at indicated pH conditions for 30 minutes, whole cell extract were prepared and analyzed for pAKT. $(B)$ Phosphorylation of AKT under acidic environment is transient in MCF-7 cells but persistence in MDA-MB-231 cells. Cells were cultured at pH 6.6 for indicated times, whole cell extract were prepared and analyzed using indicated antibodies. $(C)$ Acidic environment induces phosphorylation of PDK1 in MCF-7 cells. Cells were cultured at pH 6.6 for the indicated times, whole cell extract were prepared and analyzed by Western blotting using indicated antibodies. 


\section{Acidosis induces AKT activation through thiol modification of PTEN}

The tumor suppressor PTEN, a negative regulator of AKT signaling, is known to undergo inactivation (oxidation) by ROS [18]. Since acidosis-induced ROS production and AKT phosphorylation were abrogated by ROS scavengers, we examined if activation of AKT is mediated through inactivation of PTEN. We found that acidosis induced PTEN oxidation in both MCF7 and MDA-MB-231 cells (Fig. 6A). Furthermore, the reducing agent dithiothreitol (DTT) reversed the acidosisinduced PTEN oxidation in both cell lines, suggesting the possibility of involvement of cysteine residues.
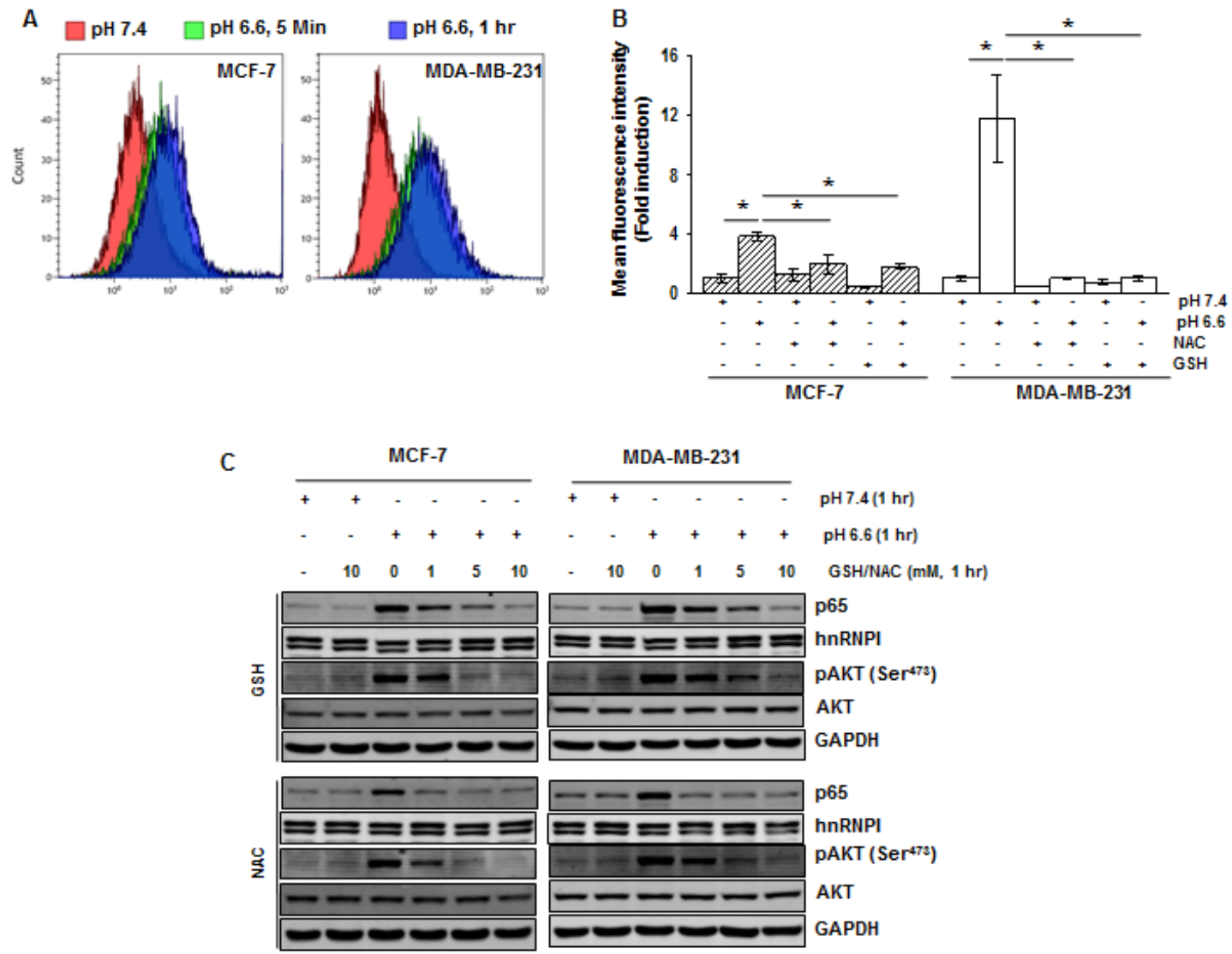

D
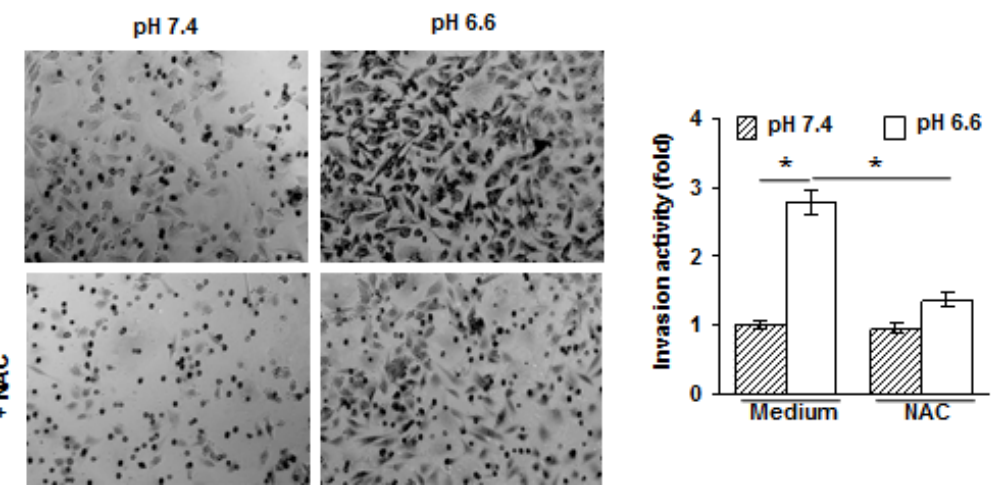

Figure 4: The acidosis-induced activation of NF- $\mathbf{B}$ and AKT is mediated through ROS generation. $(A)$ Cells were cultured at $\mathrm{pH} 7.4$ and $\mathrm{pH} 6.6$ for 5 minutes and 1 hour. The intracellular ROS levels were measured using DCFH-DA by flow cytometry. ( $B$ ) ROS generated by acidosis is suppressed by NAC and GSH. Cells were treated with NAC (10 mM) or GSH (10 mM) for $1 \mathrm{~h}$, washed off, and then cultured at $\mathrm{pH} 7.4$ or $\mathrm{pH} 6.6$ for 1 hour. The intracellular ROS levels were measured using DCFH-DA by flow cytometry. (C) Cells were treated with indicated concentrations of GSH or NAC for 1 hour, washed off, and then cultured at pH 7.4 and $\mathrm{pH} 6.6$ for 1 hour. The nuclear extracts and whole-cell extracts were analyzed by Western blotting for p65 and pAKT, respectively. (D) NAC suppresses acidosis induced invasion activity of MDA-MB-231 cells. Cells were pretreated with NAC (10 mM) for 1 hour, washed off, and then cultured at $\mathrm{pH}$ 7.4 or $\mathrm{pH} 6.6$ for 48 hours. Invasion activity was measured using Matrigel invasion chambers. ${ }^{*}, p<0.05$. 
Consistent with previous reports, we also found that hydrogen peroxide oxidized PTEN which can be reversed by DTT. PTEN has two essential catalytic cysteine residues $\left(\mathrm{Cys}^{71}\right.$ and $\mathrm{Cys}^{124}$ ) that are subject to thiol modification by ROS [18]. To determine if these residues are involved in acidosis-mediated PTEN oxidation and AKT phosphorylation, we transfected the PTEN deficient BT-549 cells with wild type Myc-PTEN or mutant MycPTEN with Cys ${ }^{71}$ Ser and Cys ${ }^{124}$ Ser. We detected acidosisinduced oxidation of PTEN in cells expressing wild type PTEN but not in those expressing mutant PTEN (Fig. $6 B$ ). Importantly, PTEN deficient cells expressed a high level of basal phospho-AKT (Fig. $6 B$ and Fig S3) that was suppressed by the introduction of wild type PTEN but not by mutant PTEN (Fig. 6B). Furthermore, acidosis induced phosphorylation of AKT in cells expressing wild type PTEN but not in those expressing mutant PTEN. These results suggest that $\mathrm{Cys}^{71}$ and $\mathrm{Cys}^{124}$ residues of PTEN are essential for the acidosis-induced AKT phosphorylation. We also found that acidosis was unable to induce AKT phosphorylation in PTEN deficient BT549 and MDAMB-468 cells (Fig. 6C), further supporting the role of
PTEN in acidosis-mediated AKT phosphorylation.

\section{NADPH oxidase (NOX) contributes to acidosis- induced ROS generation}

Finally, we determined whether the family of NADPH oxidase (NOX) is involved in acidosisinduced ROS because they are the most likely source of ROS produced in the cell [19]. We treated cells with diphenyleneiodonium (DPI), a pharmacological inhibitor of NOX, before culture under low $\mathrm{pH}$ conditions, and ROS was detected by the DCFH-DA method. We found that acidosis-induced ROS production was reduced from a 5.1-fold to a 2.9-fold in MCF-7 cells and from a 10fold to a 5.1-fold by DPI in MDA-MB-231 cells (Fig. $6 D)$, suggesting a role of NOX in acidosis-induced ROS generation.

\section{DISCUSSION}

The extracellular $\mathrm{pH}(\mathrm{pHe})$ of solid tumors, such as
A

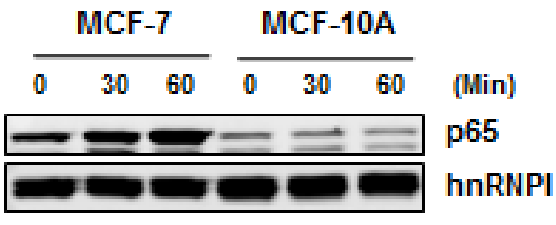

B

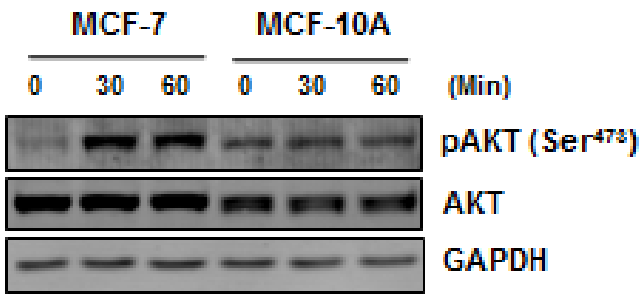

$\mathrm{C}$

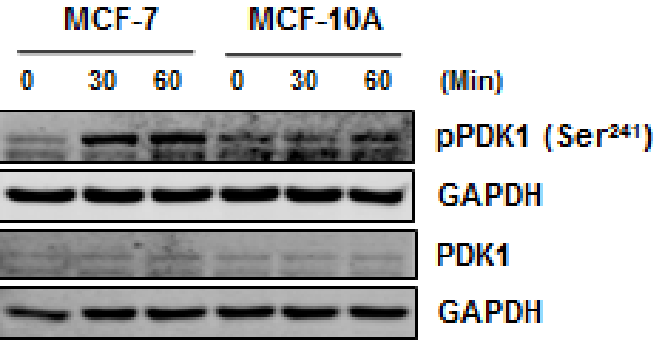

D

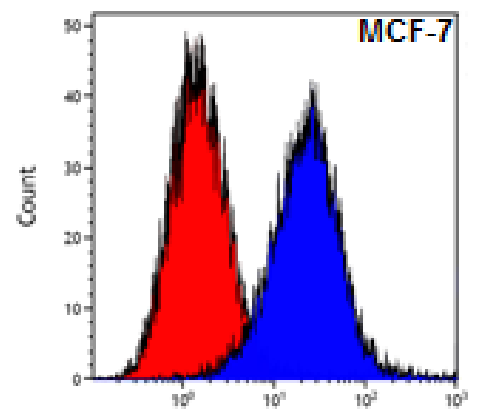

$\mathrm{pH} 6.6,1 \mathrm{hr}$

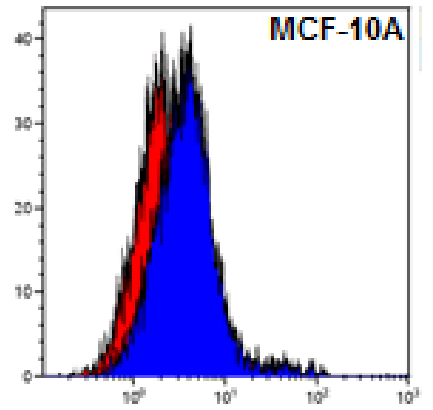

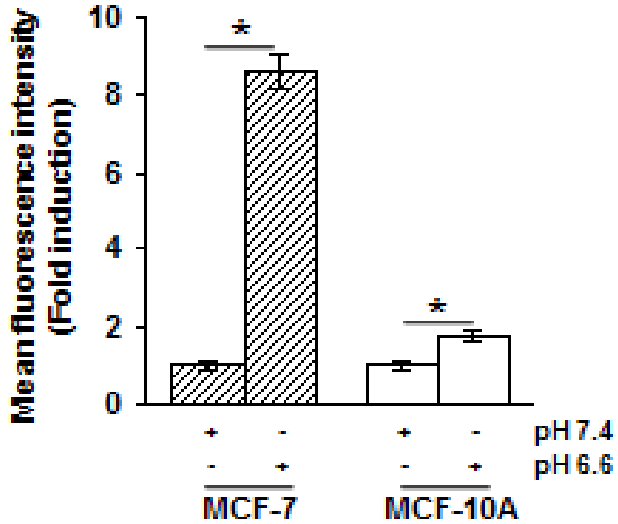

Figure 5: Acidosis does not activate NF-кB, AKT and PDK1, and induces minimal level of ROS in non-malignant cells. (A) MCF-7 and MCF-10A cells were cultured under acidic conditions for the indicated time and the nuclear extracts were used to analyze p65 by Western blotting. $(B, C)$ The whole-cell extracts were analyzed using indicated antibodies by Western blotting. $(D)$ Cells were cultured at $\mathrm{pH} 7.4$ and $\mathrm{pH} 6.6$ for 1 hour and the intracellular ROS level was measured using DCFH-DA by flow cytometry. ${ }^{*}, p<0.05$. 
breast tumors, is more acidic than that of normal tissue primarily due to high glycolysis and poor perfusion within tumors; pHe values could reach 6.2 6.8 [20]. In some extreme cases, interstitial $\mathrm{pH}$ values could even be as low as 5.8 [21]. Thus, these tumor cells have to employ various mechanisms to remove intracellular acids in order to maintain physiological $\mathrm{pHi}$, including $\mathrm{Na}$-driven proton extrusion, V-type ATPases, $\mathrm{Na}^{+} / \mathrm{H}^{+}$exchangers (NHEs) and those facilitated by carbonic anhydrases [22, 47]. As a result, $\mathrm{pHe}$ becomes more acidic, which is often harmful to normal cells. However, such low pHe may benefit tumor cells for their migration and invasion [23]. These findings suggest that tumor cells have adapted well to extracellular acidosis which, furthermore, may be used by tumor cells as a means to promote their invasion and metastasis [4].

Acidic tumor microenvironment has been shown to produce multiple effects on tumor cells and contribute to invasiveness and metastasis. For instance, acidosisinduced cell invasion has been reported in variety of cancer including melanoma [24, 25], cervical cancer [26],
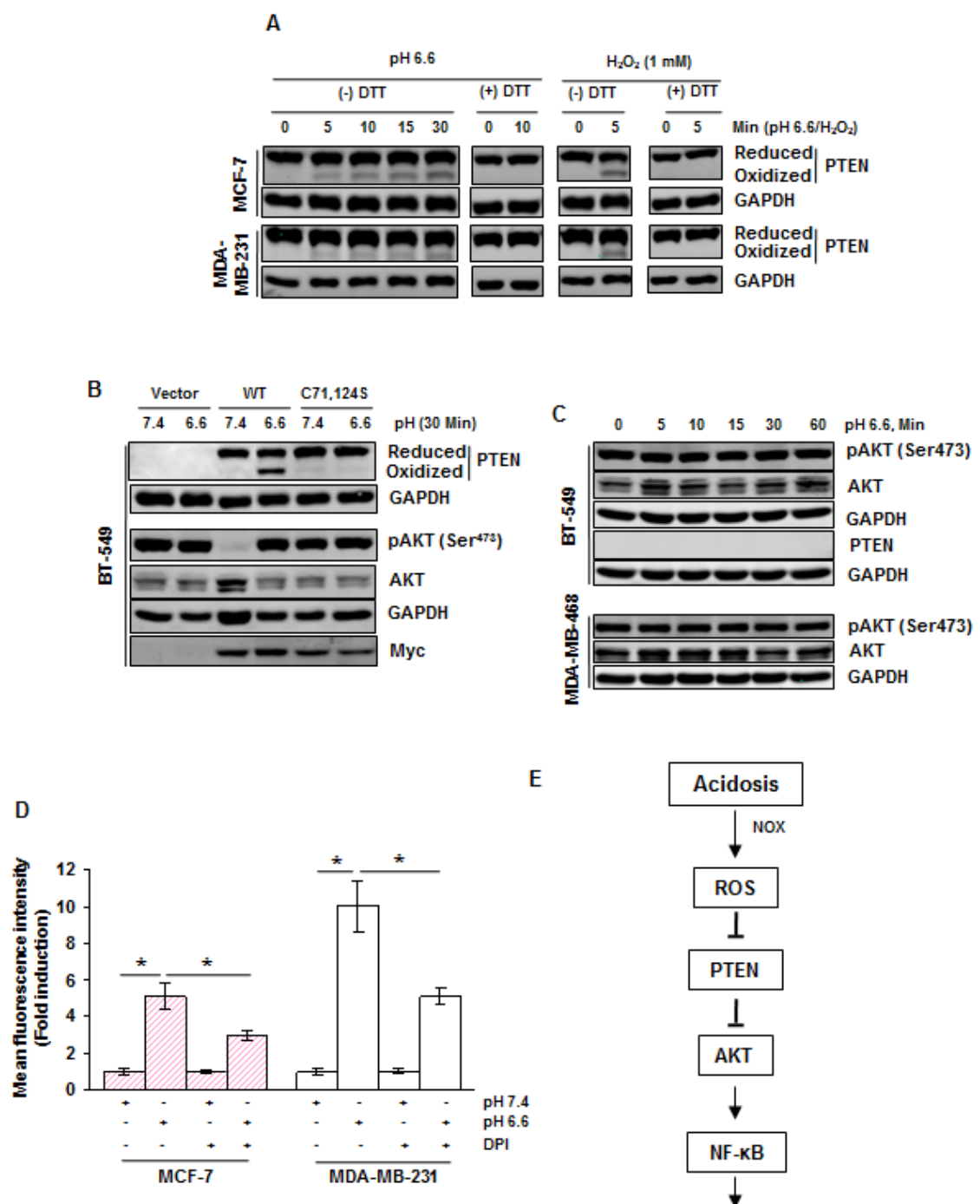

E

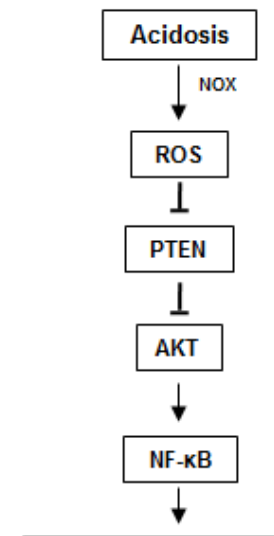

Breast cancer invasion

Figure 6: Acidosis oxidizes PTEN and presence of PTEN is required for acidosis induced AKT activation in breast cancer cells. $(A)$ MCF-7 and MDA-MB-231 cells were cultured under acidic conditions or treated with $1 \mathrm{mM} \mathrm{H}_{2} \mathrm{O}_{2}$ for the indicated time. The whole cell extract was then alkylated with NEM and subjected to nonreducing SDS-PAGE followed by Western blot analysis using indicated antibodies. For PTEN blot, upper band indicates the reduced form while lower band indicates the oxidized form of PTEN. $(B)$ BT-549 cells transiently expressing wild-type and mutant $\left(\mathrm{C}^{71} \mathrm{~S}, \mathrm{C}^{124} \mathrm{~S}\right)$ PTEN plasmids were exposed to acidosis for 30 minutes, whole cell extracts were prepared and analyzed for indicated proteins by Western blot analysis. (C) PTEN deficient cells (BT-549, MDA-MB-468) were exposed to acidosis for the indicated times, whole cell extracts were prepared and analyzed for indicated proteins by Western blot analysis. $(D)$ The generation of ROS under acidic conditions is mediated through NOX in breast cancer cells. Cells were cultured at $\mathrm{pH}$ 7.4 or $\mathrm{pH} 6.6$ without and with $20 \mu \mathrm{M}$ DPI and analyzed for intracellular ROS levels using DCFH-DA by flow cytometry. (E) A schematic diagram showing the signaling pathways by which acidosis promotes breast cancer invasion. 
and prostate cancer [27]. Moreover, acidosis can activate $\mathrm{NF}-\kappa \mathrm{B}$ in melanoma [10], osteosarcoma [28], ovarian [11] as well as pancreatic, colon and prostate cancer [12], suggesting the importance of NF- $\mathrm{NB}$ in cell invasion. In support of this view, we show that acidosis induces NF$\kappa \mathrm{B}$ activation in breast cancer cells, as determined by Western blot, reporter gene assay and immunofluorescence staining. Moreover, this is a specific effect of acidosisinduced NF- $\kappa$ B because acidosis does not affect STAT3 activity. Finally, invasion activity is suppressed by gene silencing of $\mathrm{NF}-\kappa \mathrm{B}$ p 65 . As a result, acidosis induces the $\mathrm{NF}-\kappa \mathrm{B}$ target gene CXCR4. Notably, acidosis induced $\mathrm{NF}-\kappa \mathrm{B}$ p65 activation was found to be more in MCF-7 cells in comparison to MDAMB-231 cells. However, acidosis does not promote invasiveness in MCF-7 cells (unpublished observations). Although NF- $\mathrm{BB}$ p65 is one of the important contributing molecules facilitating invasiveness of breast cancer cells, there are several other factors that can mask the effects of p65. For example, MCF-7 cells lack CD44 $/ \mathrm{CD} 24^{-}$subpopulations, a marker associated with invasiveness, whereas MDA-MB-231 cells have high $\mathrm{CD}_{4} 4^{+} \mathrm{CD} 24^{-}$subpopulations [29]. The expression levels of other pro-invasive genes such as interleukin (IL)-8, and urokinase plasminogen activator (uPA) are higher in MDA-MB-231 cells in comparison to MCF-7 cells [30]. Furthermore, MCF-7 cells express high level of E-cadherin, an epithelial adhesion molecule that prevents invasiveness of carcinoma cells, whereas MDAMB-231 cells lack E-cadherin. It is likely that the effects of these molecules overweigh the effects of NF- $\kappa B$ p65 and thus MCF-7 cells remains non-invasive.

However, the underlying mechanism of how acidosis induces intracellular signaling pathways, particularly NF$\kappa \mathrm{B}$ activation, is poorly understood. The present study demonstrates a series of signaling events upon acidosis (Fig 6E). At the top of acidosis-induced signaling is ROS production, which inactivates PTEN through oxidation. As a major phosphatase and inhibitor, PTEN counteracts the action of PI3K. This may explain why PDK1 and AKT are activated upon acidosis. Activated AKT serves as an upstream signaling molecule for NF- $\kappa \mathrm{B}$ through $\mathrm{I} \kappa \mathrm{B} \alpha$ kinase (IKK) and I $\kappa \mathrm{B} \alpha$ [31]. Degradation of I $\mathrm{B} \alpha$ causes $\mathrm{NF}-\kappa \mathrm{B}$ to move into the nucleus to regulate a specific set of genes.

In this regard, we showed that acidosis-induced $\mathrm{I} \kappa \mathrm{B} \alpha$ degradation is concomitant with $\mathrm{I} \kappa \mathrm{B}$ phosphorylation, p65 phosphorylation and p65 nuclear translocation. Although numerous kinases are involved in NF- $\kappa \mathrm{B}$ activation, IKK complex is an important site for the integration of signals that regulate the NF- $\kappa \mathrm{B}$ pathway $[13,32]$ and AKT reportedly functions as an immediate upstream molecule of IKK [33]. At upstream of AKT, PDK1 can serves as a kinase for AKT and it is activated by phosphatidylinositol4,5-trisphosphate $(\mathrm{PI}(3,4,5) \mathrm{P} 3)$, a second messenger that is controlled by phosphatidylinositol 3-kinase (PI3K) [34]. This allows the recruitment of PDK1 and AKT into the plasma membrane [35] and subsequent activation of AKT by PDK1.

On the other hand, PTEN, as a phosphatase, is able to remove phosphate attached to the 3 '-hydroxyl group of the PI $(3,4,5) \mathrm{P} 3$ [36]. Therefore, inhibition of PTEN elevates intracellular level of $\mathrm{PI}(3,4,5) \mathrm{P} 3$, leading to AKT activation. Cells at pH 6.6 in 5 minutes generate an oxidized (inactive) form of PTEN that migrates faster on the non-reducing gel. The crystal structure of human PTEN has revealed the presence of two essential adjacent cysteine residues at 71 and 124 positions in its catalytic domain that are prone to oxidation (inactivation) by ROS to form a disulfide bond [18]. Dithiothreitol and mutations of $\mathrm{Cys}^{71}$ and $\mathrm{Cys}^{124}$ of PTEN to Ser block acidosis-induced PTEN oxidation. The introduction of wild type PTEN in PTEN deficient cells significantly reduces the basal level of pAKT, whereas mutant PTEN has a minimal effect. In agreement with these observations, catalytically active form of PTEN has been shown to suppress basal activation of AKT [37, 38]. Furthermore, acidosis enhances the level of pAKT in cells expressing wild type PTEN but not in those expressing mutant PTEN. We speculate that acidosis-mediated ROS production induces disulfide bond formation between $\mathrm{Cys}^{71}$ and $\mathrm{Cys}^{124}$ of PTEN that causes the loss of its phosphatase activity, resulting in enhanced AKT phosphorylation. Finally, acidosis is unable to induce AKT activation in PTEN deficient cells, further indicating that PTEN is required for acidosis-induced AKT activation.

Our study suggests that ROS serves as a top signal in response to acidosis. First, acidosis induces ROS production in both MCF-7 and MDA-MB-231 cells. Second, ROS scavengers are able to suppress ROS production. Third, AKT and NF- $\mathrm{AB}$ activation are also suppressed by ROS scavengers. Fourth, ROS scavengers suppress acidosis-induced invasion activity. However, detail mechanisms by which acidosis induces ROS remain to be determined yet. Since the NADPH oxidase (NOX) inhibitor DPI can suppress acidosis-induced ROS production, it is possible that breast cancer cells generate ROS under acidic conditions in part through NOX. Our observation is not consistent with a previous study that acidosis-induced ROS generation is independent of NOX in prostate cancer cells [39]. It remains to be determined whether this discrepancy is due to the use of different types of cancer cells. Since NOX is present in cell's plasma membrane [40], plasma membrane appears to be major site of ROS production under acidic conditions. Thus, it would be interesting to determine whether NOX interacts with molecular sensors such as proton-sensing G-protein coupled receptors (GPCRs) or acid-sensing ion channels (ASICs) [22] to induce ROS production.

However, this acidosis-mediated signaling pathway we demonstrate here does not exist in all tumors. For instance, PTEN mutations occurs in a variety of cancer types including breast cancer [41]. Thus, a question is 
whether PTEN mutant tumor cells are still responsive to acidosis. If so, what are alternative pathways? We found that acidosis also activates ERK1/2, which can be suppressed by both GSH and NAC in MCF-7 cells (Gupta et el., unpublished). Hence, it would be interesting to determine whether activation of ERK1/2 can bypass AKT to activate NF- $\kappa \mathrm{B}$ or a further downstream factor. Given the heterogeneity of tumor cells, it is likely that different types of tumor cells may have different intracellular signaling pathways in response to acidosis. Therefore, further characterization of acidosis-induced signaling in various types of tumor cells will provide more comprehensive insight into acidosis-induced cell invasion.

One of the most interesting findings is cancer specific acidosis-induced ROS production and activation of AKT and NF- $\mathrm{AB}$. ROS is significantly high in breast cancer MCF-7 cells compared to non-malignant MCF-10A cells. Due to the unique metabolic profile, tumor cells may have elevated activity of NOX that may lead to enhanced ROS generation in these cells in comparison with normal cells. It is possible that a cellular threshold of ROS is critical to activation of above key events [42]. Because of their inherent capability to survive under oxidative stress, cancer cells can accumulate ROS to achieve a high cellular threshold under acidic conditions. On the other hand, normal or non-malignant cells may lack such a mechanism so that they cannot survive well under acidosis. Therefore, this high level of ROS in cancer cells may help them to achieve the acidosis-induced signaling cascades [43]. Evidently, this selectivity may provide a great opportunity for intervention. Of course, studies are underway to widen the relevance of these observations using multiple tumor types and non-malignant cells.

\section{MATERIALS AND METHODS}

\section{Reagents}

DMEM/F12 and RPMI 1640 media were obtained from Lonza (Walkersville, MD). The fetal bovine serum (FBS), aprotonin, leupeptin, benzamidine hydrochloride, diphenyleneiodonium chloride (DPI), 2',7'-dichlorofluorescin diacetate (DCFH-DA), N-acetylL-cysteine (NAC), L-glutathione reduced (GSH), TNF- $\alpha$, N-ethylmaleimide (NEM), dithiothreitol, and $\beta$-glycerophosphate disodium salt hydrate were obtained from Sigma-Aldrich (St. Louis, MO). The antibodies were obtained from following sources: NF- $\kappa$ B-p65, poly (ADP-ribose) polymerase (PARP), PTEN, PDK1, STAT3, pp65 $\left(\operatorname{Ser}^{536}\right), \operatorname{pI\kappa B} \alpha\left(\operatorname{Ser}^{32 / 36}\right)$, pAKT $\left(\operatorname{Ser}^{473}\right.$ and $\left.\mathrm{Thr}^{308}\right)$, pPDK1 $\left(\operatorname{Ser}^{241}\right)$, and pSTAT3 $\left(\operatorname{Ser}^{727}\right)$ from Cell Signaling (Danvers, MA); AKT from Santa Cruz Biotechnology (Santa Cruz, CA); I $\mathrm{B} \alpha$ from Imgenex (San Diego, CA); CXCR4 from Abcam (Cambridge, MA); GAPDH from
ProteinTech (Chicago, IL). Antibody against hnRNP I was custom made. The goat anti-rabbit Alexafluor 488 was obtained from invitrogen (Carlsbad, CA) while secondary antibodies conjugated with IRDye $800 \mathrm{CW}$ or IRDye 680 were purchased from LI-COR Biosciences (Lincoln, $\mathrm{NE}$ ). The sources of other materials were: BD Matrigel invasion chamber from BD Biosciences (San Jose, CA); MG-132 from Calbiochem (Billerica, MA); phusion enzyme for PCR reactions and cloning purpose, and $\mathrm{H}_{2} \mathrm{O}_{2}$ from Fischer Scientific (Pittsburgh, PA); RNAfectin from Applied Biological Materials (Vancouver, Canada); and luciferase assay kit from Promega (Madison, WI). PCR primers were purchased from IDT (Coralville, IA) (Supplementary Table S1). siRNA sources were: control siRNA from Fisher Scientific (Pittsburgh, PA); p65 siRNA from Cell Signaling (Danvers, MA).

\section{Cell lines}

All cell lines were obtained from American Type Culture Collection (Manassas, VA) otherwise stated. MCF-7, MDA-MB-231, and BT-549 cells were cultured in RPMI-1640 medium with 10\% FBS and $2 \mathrm{mM}$ glutamine. MDA-MB-468 cells were cultured in DMEM/F12 with $10 \%$ FBS and $2 \mathrm{mM}$ glutamine while SUM-149 cells were cultured in Ham's F12 containing 10\% FBS, $5 \mu \mathrm{g} / \mathrm{mL}$ insulin and $1 \mu \mathrm{g} / \mathrm{mL}$ hydrocortisone. MCF-10A cells were cultured in DMEM/F-12 with 5\% FBS, 1\% L-glutamine, $10 \mathrm{ng} / \mathrm{mL}$ EGF, $0.5 \mu \mathrm{g} / \mathrm{mL}$ hydrocortisone, and $10 \mu \mathrm{g} / \mathrm{mL}$ insulin. All culture media were supplemented with 100 units $/ \mathrm{mL}$ penicillin and $100 \mu \mathrm{g} / \mathrm{mL}$ streptomycin.

\section{Immunofluorescence staining and confocal microscopy}

To determine the subcellular localization of NF- $\kappa \mathrm{B}$ p65 in cells grown under normal and low pH medium, an immunofluorescence staining was performed as described previously [44]. In brief, cells were fixed with $4 \%$ paraformaldehyde ( $\mathrm{pH} 7.2$ ), permeabilized with Triton $\mathrm{X}-100$, and blocked with $2.5 \%$ bovine serum albumin. Cells were then incubated with rabbit polyclonal anti-p65 $(1: 100)$ at $4^{\circ} \mathrm{C}$ overnight, followed with goat anti-rabbit immunoglobulin G Alexa Fluor 488 (1:100) for $1 \mathrm{~h}$. After nuclear staining with propidium iodide $(1 \mu \mathrm{g} / \mathrm{mL})$ and mounting, the cells were examined under Nikon $\mathrm{C} 1$ confocal scanning microscope at Imaging Core of Center for Psychiatric Neuroscience at UMMC.

\section{Invasion assay}

Cell invasion activity was determined in vitro using BD BioCoat tumor invasion system from BD Biosciences (San Jose, CA), which contains an $8-\mu \mathrm{m}$ polyethylene 
terephthalate membrane with a thin layer of reconstituted Matrigel basement membrane matrix. Cells $\left(2 \times 10^{4}\right)$ in $500 \mu \mathrm{L}$ medium were added to the wells and incubated at $37^{\circ} \mathrm{C}$ in an incubator equipped with $5 \% \mathrm{CO}_{2}$. After 24 hours, cells remaining in the upper membrane surface were removed with a cotton swab, whereas the cells on the lower surface were fixed in methanol, stained with crystal violet and counted as described before [45].

\section{Plasmid construction}

To construct NF- $\kappa \mathrm{B}$-luciferase reporter system, 5 copies of NF- $\kappa B$ response element in front of minimal promoter (TATA) was custom synthesized as a gBlock (IDT) which was then used as a template for PCR amplification using primers pGL3-B-Xho1-5.1 and TK mini-Luc-Nco1-3.1 (Supplementary Table S1). The PCR product was cloned into the luciferase reporter vector (PGL3 basic) at XhoI and NcoI sites. Wild type PTEN and mutant PTEN (C71S and C124S) were cloned into pCDH-CMV-copGFP (System Biosciences, Mountain View, CA). For wild type PTEN, we used primers PTEN-Myc-R1-5.1 and PTEN-Not1-3.1, tagged with N-terminal Myc. For mutant PTEN, we used primers PTEN-C71S-5.1, PTEN-C71S-3.1, PTEN-C124S-5.1 and PTEN-C124S-3.1 to introduce two mutant sites (C71S and C124S). The cloned mutant PTEN was also tagged with N-terminal Myc. All PCR products were verified by DNA sequencing.

\section{NF-кB-dependent reporter assay}

To examine the effect of acidosis on NF- $\kappa \mathrm{B}$ dependent reporter gene transcription, $\mathrm{MCF}-7$ cells were transiently transfected with the NF- $\mathrm{BB}$ reporter plasmid before culture under normal or low $\mathrm{pH}$ medium. The luciferase activity was measured using whole cell lysate and a luciferase assay kit following the manufacturer's instructions [46]. The firefly luciferase activity was normalized to renilla luciferase activity.

\section{Transfection}

Cells were transfected with siRNAs using RNAfectin reagent essentially following the manufacturer's instructions as described before [45].

\section{Measurement of intracellular ROS}

We used membrane-permeable DCFH-DA dye to measure intracellular ROS generation by flow cytometry. Cells were cultured under normal or low $\mathrm{pH}$ medium in the presence of dye and the assay was conducted according to a previously published protocol [48].

\section{Western blot}

The protein extract from cytoplasmic, nuclear and whole cell extracts were prepared, and Western blot analysis was carried out as described previously [49].

\section{Preparation of nuclear, cytoplasmic, and whole cell extracts}

The nuclear, cytoplasmic and whole cell extracts were prepared as described previously [50] and the protein concentration in these fractions was determined by the Bradford method.

\section{Identification of reduced and oxidized forms of PTEN}

To detect oxidized and reduced forms of PTEN, we followed a method described previously [18]. In brief, whole cell protein extract was prepared from normal and treated cells in a whole cell lysis buffer containing 40 $\mathrm{mM}$ NEM. An equal amount of protein was resolved by $10 \%$ SDS-PAGE under non-reducing conditions; oxidized and reduced forms of PTEN were detected by Western blotting.

\section{Statistical methods}

Different parameters were monitored in normal and treated groups. The two groups were compared by an unpaired Student's $t$ test. A value of $P<0.05$ was considered statistically significant.

\section{ACKNOWLEDGEMENTS}

This work is supported in part by a grant from the National Institutes of Health R01 CA154989 (YM) and a grant from UMMC's Intramural Research Support Program (SCG). Imaging Core of Center for Psychiatric Neuroscience at UMMC is supported by COBRE grant GM103328.

\section{REFERENCES}

1. Valastyan S and Weinberg RA. Tumor metastasis: molecular insights and evolving paradigms. Cell. 2011; 147(2):275-292.

2. Comen EA. Tracking the seed and tending the soil: evolving concepts in metastatic breast cancer. Discov Med. 2012; 14(75):97-104.

3. Gallagher FA, Kettunen MI, Day SE, Hu DE, ArdenkjaerLarsen JH, Zandt R, Jensen PR, Karlsson M, Golman $\mathrm{K}$, Lerche $\mathrm{MH}$ and Brindle KM. Magnetic resonance 
imaging of $\mathrm{pH}$ in vivo using hyperpolarized 13C-labelled bicarbonate. Nature. 2008; 453(7197):940-943.

4. Gatenby RA and Gillies RJ. Why do cancers have high aerobic glycolysis? Nature reviews Cancer. 2004; 4(11):891-899.

5. Leontieva OV and Blagosklonny MV. Yeast-like chronological senescence in mammalian cells: phenomenon, mechanism and pharmacological suppression. Aging. 2011; 3(11):1078-1091.

6. Abbey $\mathrm{CK}$, Borowsky AD, McGoldrick ET, Gregg JP, Maglione JE, Cardiff RD and Cherry SR. In vivo positron-emission tomography imaging of progression and transformation in a mouse model of mammary neoplasia. Proc Natl Acad Sci U S A. 2004; 101(31):11438-11443.

7. Estrella V, Chen T, Lloyd M, Wojtkowiak J, Cornnell HH, Ibrahim-Hashim A, Bailey K, Balagurunathan Y, Rothberg JM, Sloane BF, Johnson J, Gatenby RA and Gillies RJ. Acidity generated by the tumor microenvironment drives local invasion. Cancer research. 2013; 73(5):1524-1535.

8. Robey IF, Baggett BK, Kirkpatrick ND, Roe DJ, Dosescu J, Sloane BF, Hashim AI, Morse DL, Raghunand N, Gatenby RA and Gillies RJ. Bicarbonate increases tumor $\mathrm{pH}$ and inhibits spontaneous metastases. Cancer Res. 2009; 69(6):2260-2268.

9. Chaturvedi MM, Sung B, Yadav VR, Kannappan R and Aggarwal BB. NF-kappaB addiction and its role in cancer: 'one size does not fit all'. Oncogene. 2011; 30(14):16151630.

10. Peppicelli S, Bianchini F, Contena C, Tombaccini D and Calorini L. Acidic pH via NF-kappaB favours VEGF-C expression in human melanoma cells. Clinical \& experimental metastasis. 2013; 30(8):957-967.

11. $\mathrm{Xu} \mathrm{L}$ and Fidler IJ. Acidic $\mathrm{pH}$-induced elevation in interleukin 8 expression by human ovarian carcinoma cells. Cancer Res. 2000; 60(16):4610-4616.

12. Shi Q, Le X, Wang B, Xiong Q, Abbruzzese JL and Xie K. Regulation of interleukin-8 expression by cellular $\mathrm{pH}$ in human pancreatic adenocarcinoma cells. J Interferon Cytokine Res. 2000; 20(11):1023-1028.

13. Gupta SC, Sundaram C, Reuter S and Aggarwal BB. Inhibiting NF-kappaB activation by small molecules as a therapeutic strategy. Biochim Biophys Acta. 2010; 1799(10-12):775-787.

14. Aggarwal BB. Nuclear factor-kappaB: the enemy within. Cancer Cell. 2004; 6(3):203-208.

15. Stubbs M, McSheehy PM, Griffiths JR and Bashford CL. Causes and consequences of tumour acidity and implications for treatment. Mol Med Today. 2000; 6(1):1519.

16. Glitsch M. Protons and $\mathrm{Ca} 2+$ : ionic allies in tumor progression? Physiology (Bethesda). 2011; 26(4):252-265.

17. Morgan MJ and Liu ZG. Crosstalk of reactive oxygen species and NF-kappaB signaling. Cell Res. 2011; 21(1):103-115.
18. Lee SR, Yang KS, Kwon J, Lee C, Jeong W and Rhee SG. Reversible inactivation of the tumor suppressor PTEN by H2O2. J Biol Chem. 2002; 277(23):20336-20342.

19. Bonner MY and Arbiser JL. Targeting NADPH oxidases for the treatment of cancer and inflammation. Cellular and molecular life sciences : CMLS. 2012; 69(14):2435-2442.

20. Hashim AI, Zhang X, Wojtkowiak JW, Martinez GV and Gillies RJ. Imaging $\mathrm{pH}$ and metastasis. NMR in biomedicine. 2011; 24(6):582-591.

21. Tannock IF and Rotin D. Acid pH in tumors and its potential for therapeutic exploitation. Cancer research. 1989; 49(16):4373-4384.

22. Damaghi M, Wojtkowiak JW and Gillies RJ. pH sensing and regulation in cancer. Frontiers in physiology. 2013; $4: 370$.

23. Hanahan D and Weinberg RA. Hallmarks of cancer: the next generation. Cell. 2011; 144(5):646-674.

24. Rofstad EK, Mathiesen B, Kindem K and Galappathi K. Acidic extracellular $\mathrm{pH}$ promotes experimental metastasis of human melanoma cells in athymic nude mice. Cancer Res. 2006; 66(13):6699-6707.

25. Moellering RE, Black KC, Krishnamurty C, Baggett BK, Stafford P, Rain M, Gatenby RA and Gillies RJ. Acid treatment of melanoma cells selects for invasive phenotypes. Clin Exp Metastasis. 2008; 25(4):411-425.

26. Lee WY, Huang SC, Hsu KF, Tzeng CC and Shen WL. Roles for hypoxia-regulated genes during cervical carcinogenesis: somatic evolution during the hypoxiaglycolysis-acidosis sequence. Gynecol Oncol. 2008; 108(2):377-384.

27. Castellone RD, Leffler NR, Dong L and Yang LV. Inhibition of tumor cell migration and metastasis by the proton-sensing GPR4 receptor. Cancer Lett. 2011; 312(2):197-208.

28. Matsubara T, Diresta GR, Kakunaga S, Li D and Healey JH. Additive Influence of Extracellular pH, Oxygen Tension, and Pressure on Invasiveness and Survival of Human Osteosarcoma Cells. Front Oncol. 2013; 3:199.

29. Charafe-Jauffret E, Ginestier C, Monville F, Finetti P, Adelaide J, Cervera N, Fekairi S, Xerri L, Jacquemier J, Birnbaum D and Bertucci F. Gene expression profiling of breast cell lines identifies potential new basal markers. Oncogene. 2006; 25(15):2273-2284.

30. Sheridan C, Kishimoto H, Fuchs RK, Mehrotra S, BhatNakshatri P, Turner $\mathrm{CH}$, Goulet R, Jr., Badve S and Nakshatri H. CD44+/CD24- breast cancer cells exhibit enhanced invasive properties: an early step necessary for metastasis. Breast cancer research : BCR. 2006; 8(5):R59.

31. Dan HC, Cooper MJ, Cogswell PC, Duncan JA, Ting JP and Baldwin AS. Akt-dependent regulation of NF-\{kappa $\mathrm{B}$ is controlled by mTOR and Raptor in association with IKK. Genes \& development. 2008; 22(11):1490-1500.

32. Perkins ND. The diverse and complex roles of NF-kappaB subunits in cancer. Nat Rev Cancer. 2012; 12(2):121-132. 
33. Ozes ON, Mayo LD, Gustin JA, Pfeffer SR, Pfeffer LM and Donner DB. NF-kappaB activation by tumour necrosis factor requires the Akt serine-threonine kinase. Nature. 1999; 401(6748):82-85.

34. Fayard E, Tintignac LA, Baudry A and Hemmings BA. Protein kinase B/Akt at a glance. J Cell Sci. 2005; 118(Pt 24):5675-5678.

35. Du K and Tsichlis PN. Regulation of the Akt kinase by interacting proteins. Oncogene. 2005; 24(50):7401-7409.

36. Khan KH, Yap TA, Yan L and Cunningham D. Targeting the PI3K-AKT-mTOR signaling network in cancer. Chin J Cancer. 2013; 32(5):253-265.

37. Cantley LC and Neel BG. New insights into tumor suppression: PTEN suppresses tumor formation by restraining the phosphoinositide 3-kinase/AKT pathway. Proc Natl Acad Sci U S A. 1999; 96(8):4240-4245.

38. Papa A, Wan L, Bonora M, Salmena L, Song MS, Hobbs RM, Lunardi A, Webster K, Ng C, Newton RH, Knoblauch $\mathrm{N}$, Guarnerio J, Ito K, Turka LA, Beck AH, Pinton P, et al. Cancer-associated PTEN mutants act in a dominantnegative manner to suppress PTEN protein function. Cell. 2014; 157(3):595-610.

39. Riemann A, Schneider B, Ihling A, Nowak M, Sauvant C, Thews $\mathrm{O}$ and Gekle M. Acidic environment leads to ROSinduced MAPK signaling in cancer cells. PloS one. 2011; 6(7):e22445.

40. Gupta SC, Hevia D, Patchva S, Park B, Koh W and Aggarwal BB. Upsides and downsides of reactive oxygen species for cancer: the roles of reactive oxygen species in tumorigenesis, prevention, and therapy. Antioxid Redox Signal. 2012; 16(11):1295-1322.

41. Dahia PL. PTEN, a unique tumor suppressor gene. Endocrine-related cancer. 2000; 7(2):115-129.

42. Schumacker PT. Reactive oxygen species in cancer cells: live by the sword, die by the sword. Cancer Cell. 2006; 10(3):175-176.

43. Trachootham D, Alexandre J and Huang P. Targeting cancer cells by ROS-mediated mechanisms: a radical therapeutic approach? Nat Rev Drug Discov. 2009; 8(7):579-591.

44. Sachdeva M, Liu Q, Cao J, Lu Z and Mo YY. Negative regulation of miR-145 by C/EBP-beta through the Akt pathway in cancer cells. Nucleic Acids Res. 2012; 40(14):6683-6692.

45. Sachdeva M and Mo YY. MicroRNA-145 suppresses cell invasion and metastasis by directly targeting mucin 1 . Cancer Res. 2010; 70(1):378-387.

46. Si ML, Zhu S, Wu H, Lu Z, Wu F and Mo YY. miR-21mediated tumor growth. Oncogene. 2007; 26(19):27992803.

47. Xu K, Mao X, Mehta M, Cui J, Zhang C, Mao F and Xu Y. Elucidation of how cancer cells avoid acidosis through comparative transcriptomic data analysis. PloS one. 2013; 8(8):e71177.

48. Gupta SC, Francis SK, Nair MS, Mo YY and Aggarwal
BB. Azadirone, a limonoid tetranortriterpene, induces death receptors and sensitizes human cancer cells to tumor necrosis factor-related apoptosis-inducing ligand (TRAIL) through a 553 protein-independent mechanism: evidence for the role of the ROS-ERK-CHOP-death receptor pathway. J Biol Chem. 2013; 288(45):32343-32356.

49. Huang J, Zhou N, Watabe K, Lu Z, Wu F, Xu M and Mo YY. Long non-coding RNA UCA1 promotes breast tumor growth by suppression of p27 (Kip1). Cell death \& disease. 2014; 5:e1008.

50. Gupta SC, Phromnoi K and Aggarwal BB. Morin inhibits STAT3 tyrosine 705 phosphorylation in tumor cells through activation of protein tyrosine phosphatase SHP1. Biochem Pharmacol. 2013; 85(7):898-912. 